\title{
Guest Editorial Governance and Ethics: An Indispensable Relationship
}

\author{
Anona Armstrong \\ Victoria University, Australia
}

\begin{abstract}
One of the fascinating questions of our time is why, when so much effort has gone into implementing corporate governance guidelines and raising the awareness of business ethics, stories of unethical conduct and poor governance continue to emerge on the front pages in our newspapers. Around the world financial scandals continue to occur and each time seekers of an antidote to the latest disaster call for more governance. This was evident after the 1987 securities market collapses when the Cadbury Committee and the OECD (Cadbury 1992; OECD 1999) were among many organisations which were to introduce governance regulations and guidelines over the next decade, and it is again prominent today.
\end{abstract}

In response to the increase in governance regulation, many listed companies have produced governance reports and social and human relations reports on their activities. Some such as Rio Tinto, BHP, Shell, Western Mining, Toyota and ANZ, for example, have developed major corporate programs that support governance and ethical initiatives. Various publications from the companies suggest that they consider these reports play an important part in promoting their corporate brand image.

The causes of the present financial crisis (Andrews 2008), again reported to be associated with poor governance, are evident in poor risk management, poor prudential and financial market regulation, greed, lack of ethics, and a decade of 'narrow' teaching and scholarship leading to a failure to deliver a cadre of professionals who care about ethical and social issues. These factors appear to be only marginally explained by governance theories.

Among the major theories of governance are agency theory, stakeholder theory, managerial hegemony theory, and stewardship theory ( For a review see Clarke 2004). Agency theory describes the potential conflict in interests between the owners of a corporation and its managers (the owners' agents). Based on economic theory, it assumes first, that a firm operating in a market environment has a single commitment to profit maximisation and the assumption that shareholders have a contract with the manager and, second, that the manager being a rational decision maker, will operate in their own interests to the exclusion of others' objectives. Studies of management hegemony describe how CEOs in the US controlled US boards to the point where they determined board members, controlled information and disclosure and even executive compensation. Stewardship theory is almost the opposite: managers interests are complementary to the owners and because of the managers' psychological motives, needs for achievement and responsibility, and commitment to the company, they will operate in its best interests. The fourth theory, stakeholder theory, argues that firms have a responsibility to those who are impacted by and have an impact on the firm. Because of this an enterprise operates at the centre of a set of relationships in which risk management and corporate citizenship are important aspects of operations.

The most researched theory is agency theory and much of the governance best practices found in governance guidelines can be seen as initiatives to curb the self-interests of directors and managers, by for example, by safeguarding their independence, auditing performance of boards and companies, and ensuring reporting transparency. Stakeholder theory, on the other hand, is an attempt to take a more positive view of the best of human motives by having regard to values and ethics which would influence decisions and behaviours, such as recognising the 'social contract' with a community in which a corporation operates, exercising corporate social responsibility and being a good corporate citizen (den 
Hond, de Bakker et al. 2007). All the theories have something to offer but are not the subject of this special edition.

This special edition is oriented towards raising governance issues, with less concern given to providing an in-depth analysis of governance theory or illustrating a particular disciplinary approach. The aim has been to give concrete reality to some of the specific governance problems that arise in our contemporary business environment.

The argument underlying the papers is that corporate leaders, (i.e. the boards of directors, commissioners in the case of the police force, and politicians in government), make decisions that impact on the organisations which they control. The members of company boards have not only legal duties emerging form the Corporations Law but responsibilities to comply with governance guidelines and also, because of their positions of power and influence, to their other stakeholders among whom are suppliers, creditors and employees. In particular, the purpose of this volume of papers is to add to our understanding of the factors that show how corporations continue to fail to meet governance and ethical standards and to suggest some initiatives that could address some of these factors

Rules and standards in governance and ethics provide a framework for what should be ethical decisions and practices that safeguard the financial system and investors. Yet, it appears that a lack of their implementation is associated with financial disasters. So, the first paper "Loss of Integrity: the true failure of the corporate sector" described three cases of financial failure. ENRON and HIH illustrated how lack of appropriate governance by the board, dubious accounting practices, greed and lack of respect for social values, and lack of, or incompetent, leadership led to their failure. Opes Prime, the most recent failure reported in Australia showed how a company misled and abused the trust of its clients. In this case, despite a commitment to governance, by its leading bank the ANZ, the bank's staff decisions appeared to be contaminated by conflicts of interest and driven by opportunities for personal gain. These are ethical issues.

The second paper in this special edition suggests that a new approach is needed to foster ethics in an organisation. A board's responsibilities should include the environment in which their people work. Most large corporations are now multinational with less "ties that bind" to their country of origin and even fewer commitment to the countries in which their workforce may be located. This was recognised in the issue by the OECD of the governance standards for multinational corporations (OECD 2001). The uncertainty of accountability across jurisdictions means that it is more urgent than ever before for the leaders of business to appreciate their ethical responsibilities. The paper recommends the selection of leaders based on ethical attributes and proposes the development of an ethical climate that supports ethical decision making and could promote wellbeing at work equally as health and safety measures do.

In response to a need to identify ethical leadership, the paper on the ethical component in transformational leadership takes one of the most researched leadership theories and explores whether it has an ethical component. It concludes from the research that ethics are important to leaders but that their values, rather than leadership style, determines their approach to ethical relationships with their staff.

Original versions of the final two papers were presented to the Police Audit Conference held in Melbourne. The papers present two different but complementary views on governance in public sector organisations such as a police force. The first paper discusses the context in which governance operates in a police environment, the power of the law, the relationships between morals and the law and how values underlie all principles of corporate governance. The authors conclude that the principles of corporate governance can only be evaluated if there is a standard by which it may be judged.

The second paper reviewed different means of evaluating governance. It discusses the benchmarks for governance structures, governance policy and principals and the structures and performance of boards. It introduces the 'partnership' model of governance which is today so prevalent in all public sector arrangements with business. Finally it discusses the functions and roles of police boards and the selfassessment checklist for assessing the effectiveness of a board. 
While one can bemoan the lack of governance and ethics in corporate Australia, nevertheless, the current scandals are an opportunity to seize the moment for business to implement the innovations that lead to better performance of our business and financial markets and in so doing to make for better businesses and civil societies.

The issues raised in this special edition of the Journal of Business Systems Governance and Ethics are important to all of us. The threats of terrorism and climate change are indicative of the uncertainty of our future. Decisions about the governance of corporations affect all of us. The efforts to improve governance must not waver. One cannot legislate to halt greed, opportunism or fraud, but social values and expectations can exert a powerful influence on corporations to do more than meet minimum compliance with regulations. Business is the third great institution in society, after government and the law. It can be instrumental in delivering the moral and ethical standards that society expects. We are at a time of great conflict and massive change in society. As we strive to decide what is of value, what is important to us, and what kind of society we want in the future, governance and ethics are indispensably linked.

\section{References}

Andrews, N. (2008) “Editorial Note: A further renaissance in corporate regulatory studies?" Australian Journal of Corporate Law Volume, 1-6 DOI:

Cadbury, S. A. (1992). "The Financial Aspects of Corporate Governance (Cadbury Report)." www.gee.co.uk.

Clarke, T. E. (2004). Theories of Corporate Governance. New York, Routledge.

den Hond, Frank., de Bakker, Frank, \& Neergaard, Peter. (2007). Managing Corporate Social

Responsibility in Action. Aldershop, Ashgate.

OECD, Organisation for Economic, Community and Development (1999). "Principles of Corporate

Goverancance." Retrieved Dec. 17, 2008.

www.oecd.org/daf/governance/principles.htm.

OECD, Organisation for Economic, Community and Development. (2001). "OECD Guidelines for

Multinational Enterprises." Retrieved May 30, 2001,

http://www.oecd.org//daf/investment/guidelines/mntext.htm.

\section{Profiles of the authors}

Professor Anona Armstrong AM is the former Director of the Centre for International Corporate Governance Research at Victoria University, Melbourne. Professor Armstrong is a Past President and Life Member of the Australasian Evaluation Society, and is a Fellow of the Australian Psychological Society, the Australian Institute of Company Directors, and is a Life Member of Clare Hall at Cambridge University. She has authored books and journal articles, and lectures and supervises doctoral students in management, corporate governance, and ethics.

Professor Ronald D Francis is Professorial Fellow in the Centre for International Corporate Governance Research in the Faculty of Business and Law at Victoria University in Melbourne. His background is as the author of several books and many papers on ethics and on corporate governance. Among his qualifications are psychology, philosophy, and criminology: he has many years of experience as a consultant on ethics and governance.

Dr Nuttawuth Muenjohn is a Lecturer in Management at RMIT University. He has published twentyfour refereed papers in international journals and international conference proceedings. He has supervised, as a principal supervisor, eighteen research students and taught at various universities in Australia and Thailand. His research interests are focussed on leadership and followership, expatriate management, management of host-nation subordinates and cross-cultural issues in management 
